\title{
Investigation of the morphology, biology and infestation of Mecorhis ungarica (Herbst, 1783) (Coleoptera: Rhynchitidae) associated with rosehip plants (Rosa spp.) ${ }^{1}$
}

Kuşburnu bitkileri üzerinde bulunan Mecorhis ungarica (Herbst, 1783) (Coleoptera: Rhynchitidae)'nın morfoloji, biyoloji ve zararının araştırıması

\author{
İsmail ALASERHAT ${ }^{2^{*}} \quad$ Levent GÜLTEKIN ${ }^{3}$
}

\begin{abstract}
Summary
Rosehip is an important socio-economic plant in Turkey. This study was carried out with the aim to determine morphology, biology and infestation of Mecorhis ungarica (Herbst, 1783) (Coleoptera: Rhynchitidae), which damaged rosehip fruits in Erzincan province in 2007-2008. The study was conducted in three steps, field surveys and biological and morphological studies. According to results of study, females laid eggs in flower buds or fruits, eggs hatched in 812 (10.1) days, oviposition lasted 40-45 (40) days in the nature, and daily fecundity was 1.2-1.6 (1.4) eggs. Larvae developed inside fruit, started maturing the second week of August, exiting from fruit, burrowing into the soil to build chamber for hibernation. They passed to the pupal stage at the end of third week of April in early spring, pupal development time was 8-12 (9.9) days and new generation adults emerged from soil at the last week of April. Consequently, M. ungarica completed one generation in a year. According to the results of a survey in Erzincan province in 2007 , infestation rates were $18 \%$ on flower buds and $31.7 \%$ on fruit of rosehip by eggs, larvae or adult damages of $M$. ungarica and average infestation rate was $24.85 \%$.
\end{abstract}

Key words: Rosehip, Rosa spp., Mecorhis ungarica, biology, Erzincan

\section{Özet}

Kuşburnu, Türkiye'de sosyo-ekonomik açıdan önemli bir bitkidir. Bu çalışma Erzincan ilinde 2007-2008 yıllarında, kuşburnu bitkisi üzerinde zarara sebep olan Mecorhis ungarica (Herbst, 1783) (Coleoptera: Rhynchitidae) 'nın morfolojisi, biyolojisi ve zararının belirlenmesi amacı ile yürütülmüştür. Araştırmalar; arazi sürveyleri, biyolojik çalışmalar ve morfolojik çalışmalar olmak üzere üç kısımda gerçekleştirilmiştir. Araştırmanın sonuçlarına göre, $M$. ungarica dişilerinin yumurtalarını kuşburnu bitkisinin tomurcuk veya meyvesi içerisine bıraktığı, yumurtaların 8-12 $(10,1)$ günde açıldığı, doğada yumurta bırakmanın 40-45 (40) gün sürdüğü, bir dişinin günlük yumurta veriminin 1,2$1,6(1,4)$ olduğu, larvanın meyve içerisinde beslenerek olgun hale geldiği, ağustos ayının ikinci haftasından itibaren toprağa geçerek bir kese hazırlayıp kışı bunun içerisinde geçirdiği tespit edilmiştir. Erken ilkbaharda nisan ayının üçüncü haftasında pupa dönemine geçtiği, pupa süresinin 8-12 $(9,9)$ gün olduğu ve mayıs ayının son haftasından itibaren erginlerin topraktan çıkış yaptığı belirlenmiştir. M. ungarica Erzincan ekolojik koşullarında yılda 1 döl vermektedir. Erzincan İlinde 2007 yılı sürvey çalışması sonuçlarına göre; kuşburnu tomurcuklarının \%18'i ve meyvelerin \%31,7'si $M$. ungarica'nın yumurta, larva veya erginlerinin zararına maruz kaldığı, genel bulaşıklık oranının ise $\% 24,85$ olduğu tespit edilmiştir.

\footnotetext{
1 This study was carried out as MSc thesis study in Atatürk University, Graduate School of Natural and Applied Sciences, Department of Plant Protection and supported by General Directorate of Agricultural Research and Policies (Republic of Turkey Ministry of Food, Agriculture and Livestock, Ankara)

2 Directorate of Horticulture Research Station, 24060, Erzincan, Turkey

3 Atatürk University, Faculty of Agriculture, Department of Plant Protection, 25240, Erzurum, Turkey

* Sorumlu yazar (Corresponding author) e-mail: i_alaserhat36@hotmail.com Alını̧ (Received): 22.01.2014 Kabul ediliş (Accepted): 12.06.2014
} 
Anahtar sözcükler: Kuşburnu, Rosa spp., Mecorhis ungarica, biyoloji, Erzincan

\section{Introduction}

Rosehip species grow naturally everywhere in Turkey and comprise 24 taxa in the genus Rosa L. (Rosaceae) (Davis 1972). Other common names for rosehip plants are rose apple, dog rose berries and dogberry (User 1967).

The economic importance of rosehip has increased in recent years in Turkey. Rosehips are processed as fruit juice, marmalade, pulp and tea bags in factories and enterprises in Gümüşhane, Erzincan and Tokat. Since plants are not cultivated, there is no a stable production for the industry (Bilginer et al. 1996). Naturally growing rosehip plants are effective in controlling erosion in many regions in Turkey, and plants are sometimes used as rootstocks for cultivated roses (Kocamaz and Karakoç 1994).

More than 150 insect and mite species belonging to different families are known to feed on rosehip plants e.g. Tetranychus urticae (Koch 1836) (Acarina: Tetranychidae), Aphis sp. (Hemiptera: Aphididae), Aulacaspis rosae (Bouchè 1937), Lepidosaphes ulmi (Linnaeus 1758) (Hemiptera: Diaspididae), Mecorhis ungarica (Herbst 1783) (Coleoptera: Rhynchitidae), Malacosoma franconica (Denis \& Schiffermüller 1775), M. neustria (Linnaeus 1758) (Lepidoptera: Lasiocampidae), Lymantria dispar (Linnaeus 1759), Euproctis chrysorrhoea (Linnaeus 1758) (Lepidoptera: Lymantridae), Archips rosana (Linnaeus 1758), A. podana (Scopoli 1763), A. xylosteanus (Frerot et al. 1983) (Lepidoptera: Tortricidae), Allantus balteatus (Klug 1814), A. basalis (Klug 1814), A. didymus (Klug 1818), A. viennensis (Schrank 1781), Rhogogaster chlorosoma (Benson 1943), Tenthredo livida (Linnaeus 1758) (Hymenoptera: Tenthredinidae), Arge ochropus (Gmelin 1970) (Hymenoptera: Argidae), Syrista parreyssii (Spinola 1843) (Hymenoptera: Cephidae), Diplolepis mayri (Schlechtendal 1877), D. rosae (Linnaeus 1758) (Hymenoptera: Cynipidae) (Özbek and Çalmaşur 2005).

Mecorhis ungarica is an oligophagous species causing damage to plants in the Rosaceae family (Legalov 2007). Rosaceae is the richest family of plants by Rhynchitidae species (Legalov 2005).

Distribution of M. ungarica in the world is Albania, Armenia, Austria, Azerbaijan, Belarus, Bosnia, Bulgaria, Greece, Crotia, Czech Republic, Germany, Georgia, Hungary, Iran, Iraq, Israel, Italy, Kazakhstan, Macedonia, Moldova, Poland, Russia, Slovakia, Slovenia, Syria, Turkey and Ukraine (Alonso-Zarazaga 2011, Legalov 2003; Legalov and Friedman 2007; Legalov 2007ab). So far it was recorded by various researchers, in Afyon, Ankara, Artvin, Bayburt, Burdur, Çorum, Erzincan, Erzurum, Gümüşhane, Isparta, İzmir, Konya, and Mardin provinces in Turkey (Reitter 1916; Tuatay 1963; Özbek et al. 1996; Çakırbay et al. 2000; Özbek et al. 2005).

According to a study conducted in Isparta and Burdur provinces in Turkey, adults of M. ungarica damaged buds and open flowers during the laying of eggs. Additionally,, they caused to shed by trimming opened buds. Because of this property they are called "trimming". In general, injured buds do not open or produce abnormal flowers. The level of damage was $47 \%$ in the Keçiborlu and Central districts in 1952 and 1953 (Tuatay 1963).

In a survey study conducted on rosehip pests in the Eastern Anatolia Region, M. ungarica was abundant, especially in Hacibayram village in Tercan, Saraycık and Toprakkale in Çayırlı, and Kerer, Dutlu and Dumanlı in Kemah districts in Erzincan (Çakırbay et al. 2000). However, its biology is not very well known.. 
The purpose of this study is to investigate the morphology, biology, infestation and natural activity of $M$. ungarica causing serious damage on Rosa spp. in Erzincan province.

\section{Material and Methods}

\section{Material}

The main material of the study was rosehip (Rosa spp) plants, growing naturally in the province of Erzincan, and biological periods of Mecorhis ungarica (Herbst 1783) (Coleoptera: Rhynchitidae) that damaged on them. In addition, transparent plastic or glass containers, a big culture cage, net-branch cages, pots, sterile-sandy soil and various labaratory materials were used.

\section{Method}

\section{A- Field surveys}

This study was conducted in Erzincan province in 2007-2008. Field studies, starting in early spring, the third week of April were conducted at Hacıbayram village of Tercan district (1700 m elevation), and Dutlu $(1105 \mathrm{~m})$ and Dumanlı $(1140 \mathrm{~m})$ villages of Kemah district, where rosehip plants naturally grow. The investigations and observations continued until the end of the season to determine seasonal activity, biology and infestation rate of $M$. ungarica. Field locations were visited at regular intervals (one time per week) to perform planned research. For field surveys, the Girigorov (1974) sampling method was applied (Table 1).

Table 1. Conducted survey in the rosehip areas, examined the number of bushes.

\begin{tabular}{rr}
\hline Total Number of Bush & Number of Required Investigation of Bush \\
\hline $1-20$ & Complete \\
$21-70$ & $21-30$ \\
$71-150$ & $31-40$ \\
$151-300$ & $41-80$ \\
$301-1000$ & $\% 15$ \\
\hline
\end{tabular}

\section{Infestation rate}

This study was carried out concurrently with the field surveys during the growing season. Feeding damage casued by adults was examined by visual examination. During the vegatation period, depending on the plant phenology, field locations were visited once a week. In the phenological stages of bud, flower and fruit season, 100 reproductive organs were collected randomly at each study area. The plant organs were cut with the help of a pair of scissors, thereafter this plant parts were placed in polyethylene bags by giving numbers, and brought to the labrotary in the ice box. In the laboratory, the plant organs were examined under a stereo microscope one by one, formations and numbers of damage were recorded (for example 1 egg laying hole). The same organs were cut with the help of a lancet under a stereo microscope. Available biological stages, (egg, larvae) and their numbers of individual in each bud, flower or fruit, were recorded.

\section{Seasonal activity}

The study included a series of observations and investigations conducted in the nature to determine biological stages of weevil (egg, larvae, pupae, adult) and in which dates it showed emergence once a week from early spring until the date of insect hibernating. For this study, the following parameters were used and to reveal the life cycle of this weevil species.

- The first date of insect activity in nature (in other words date of break hibernating)

- Adult activity period (the first and last dates, adults appeared in nature) 
- Larvae and pupae activity periods (the first and last dates, larvae and pupae appeared in nature)

- Transition of hibernating

\section{B- Biological studies}

\section{Mating behavior}

The mating behaviour were observed under the laboratory conditions, whether the insect needed pre-feeding before mating or not and duration of period, mating behaviour, frequency and duration of mating were identified. For this purpose, as soon as the first adults appeared in nature, 30 individuals were collected and brought to the laboratory. After separation of female and male under the stereo microscope, these were put in a transparent plastic or glass containers, each of which includes a female and two males. Before this process, parts of rosehip plant containing fresh shoots, leaves and buds (to be three) were cut and placed into the containers. To prevent of fading of shoots immediately, rubber parts impregnated with water the day before, were put into plastic bags with the closable mouth the next day and placed at the base of plastic containers. Then, the fresh shoots of rosehip plants collected from field, were dipped these rubbers to stand upright. This experiment was established with 10 replications.

\section{Daily fecundity}

Just as it was found that adult were laid eggs in nature, this experiment was commenced. For this purpose, 20 alive individuals (10 females, 10 males) were collected from the field in early spring, and they were released in a big sleeve cage covering a lateral branch of rosehip plant which is present in the field research station of Horticultural Research Institute, Erzincan. Adult weevils were kept here for 24 hours to allow them to mate before starting the daily fecundity experiment. Thereafter 2 plant organs for each of the stages of bud, flower and young fruit were placed into the plastic jars. These plant organs were from net-branch cages to protect them from being damaged by any insect. Twenty individuals were kept for 24 hours in culture cage, after they were taken from culture cage and seperated into male and female under a stereo microscope, and each of females was released in each of the jars included plants organs. After 24 hours, females were removed from the jar and plant organs in the each jar were examined one by one under a stereo microscope. Thus, the number of eggs laid by a female was found in a day. This experiment was established in 10 replications, applying 2 times throughout the season. In addition, during this experiment, the behavior of the insect egg drop was introduced by observations.

\section{Larval development}

Larvae samples obtained during the infestation rate and seasonal activity studies, were killed with ethyl acetate. After larvae samples were killed in order to prevent larvae to brown, they were kept in water at boiling points for 10 minutes, and each of the samples was put in air-tight tubes containing $70 \%$ ethyl alcohol, in different date, and preserved. The head capsule diameters and lengths of the larvae samples obtained were measured and to determined the number of instars.

\section{Hibernation behaviors}

When mature larvae started to be seen within the fruit before they left to the environment, the 100 unit fruits including larvae were collected from nature and these fruits were put two by two on each of pots including sterile-sandy soil at least $15 \mathrm{~cm}$ depth, whose bottoms firmly were fastened with wire mesh and 30 infested fruits including larvae were left in a big pot for investigations. After surface of pots were closed by tulle, pots were placed to be half of them in soil, outside in a controlled area. Every 10-15 days, after 
pots were carefully opened without spoiling the natural environment, required examinations and observations of insect developmental stages, were made 30 infested fruits in a big pot. This environment formed under outside controlled conditions, were kept here until the spring and the periods new adult generations emerged from hibernating, that is, date of starting activity of insect was determined.

\section{C- Morphological studies}

Adult individuals obtained during the studies were preserved in cotton envelopes, 20 male, 20 female individuals of them were glued, labeled and used for morphological analysis. Other biological stages of the insect (egg, larvae, pupae) were kept in $70 \%$ ethyl alcohol and the necessary measurements and photo shoots on these samples were carried out.

\section{Results and Discussion}

\section{Morphological Description of Mecorhis ungarica (Herbst, 1783)}

\section{Adult (Figures 1-2)}

Body size is 5.0-7.1 mm (average:6.2 mm, $\mathrm{n}: 20$ ). Rostrum, antenna, head, legs, base of pronotum, dorsal part of elytra (triangular-shaped narrowing backwards) and ventral surface are completely metallic black. In addition, external margins elytra are in the form of the thin strip and completely black color. Except for its base part, pronotum (sometimes apical side) and elytra is dorso-laterally reddish-cherry color. Surface of pronotum and elytra are heavily covered with perpendicular, short, black hair, similiar stuctural hairs are rare semi-upright position, in the surface of leg, antenna and the rostrum. However, these hairs on the tibia are more dense than in other sections. These hairs are shorter and more sparse on the antennal club and rostrum. Ventral surface of the body and femur sparsely covered with short, semi-erect, brown hairs.

Rostrum from base to the joint of antenna, gradually narrows and from the joint expands again towards the end of this point. The width of the terminal section is approximately 1.30-1.35 times the width of the base section. In dorsal view, there are three longitudinal carina until mid-section. In lateral view, rostrum is curved and this is more distinctive in half of apical part of rostrum. In male, the rostrum (Figure 1.A) is 1.46-1.48 times as long as of pronotum, in females (Figure 2.A) 1.84-1.89 times. Antenna is connected at a little distal the middle section of rostrum. Funicle segments are gradually shorter and thicker towards the apex; club consists of three segments. Eyes are round, slightly convex, golden yellow, brown, black or orange color. Head is small and frons is slightly rising tilted toward back.

Pronotum formed slightly as neck shape before apex, upper part convex in the basal half but decreasing gradually towards the apex, side edges narrow at the base, gradually swelling to the middle and narrowing forward again.

Elytra round-shouldered, parallel-sided and ending round at the apex; pygidium not closed by the elytra and open in both sexes. Striae narrow, formed with separated circular punctures, intervals distinctly wider than striae; elytral disc convex; scutellum clearly visible from dorsal view.

Femur swollen and strong; tibia thin, long and slender, gradually and slightly widening to the apex with two separate small spines at the intra-basal part; first tarsal segment cylindrical and approximately 1.50 times of the second segment; second segment triangular; third segment rounded, wide and twolobed, claw segment cylindrical, claws divergent with double lobes basally.

Aedeagus slightly curved, gradually narrowed from middle part to apex, and ends as reverse "U" shape (Figure 1.B); apical part of tegmen triangular with a bunch of hair at the apex (Figure 1.C). 
Investigation of the morphology, biology and infestation of Mecorhis ungarica (Herbst, 1783) (Coleoptera: Rhynchitidae) associated with rosehip plants (Rosa spp.)

For the male, tergit VIII and spicum gastrale are as in Fig. $1 \mathrm{D}$; for the female, tergit VIII and spiculum ventrale are as in Fig. $2 \mathrm{~B}$.

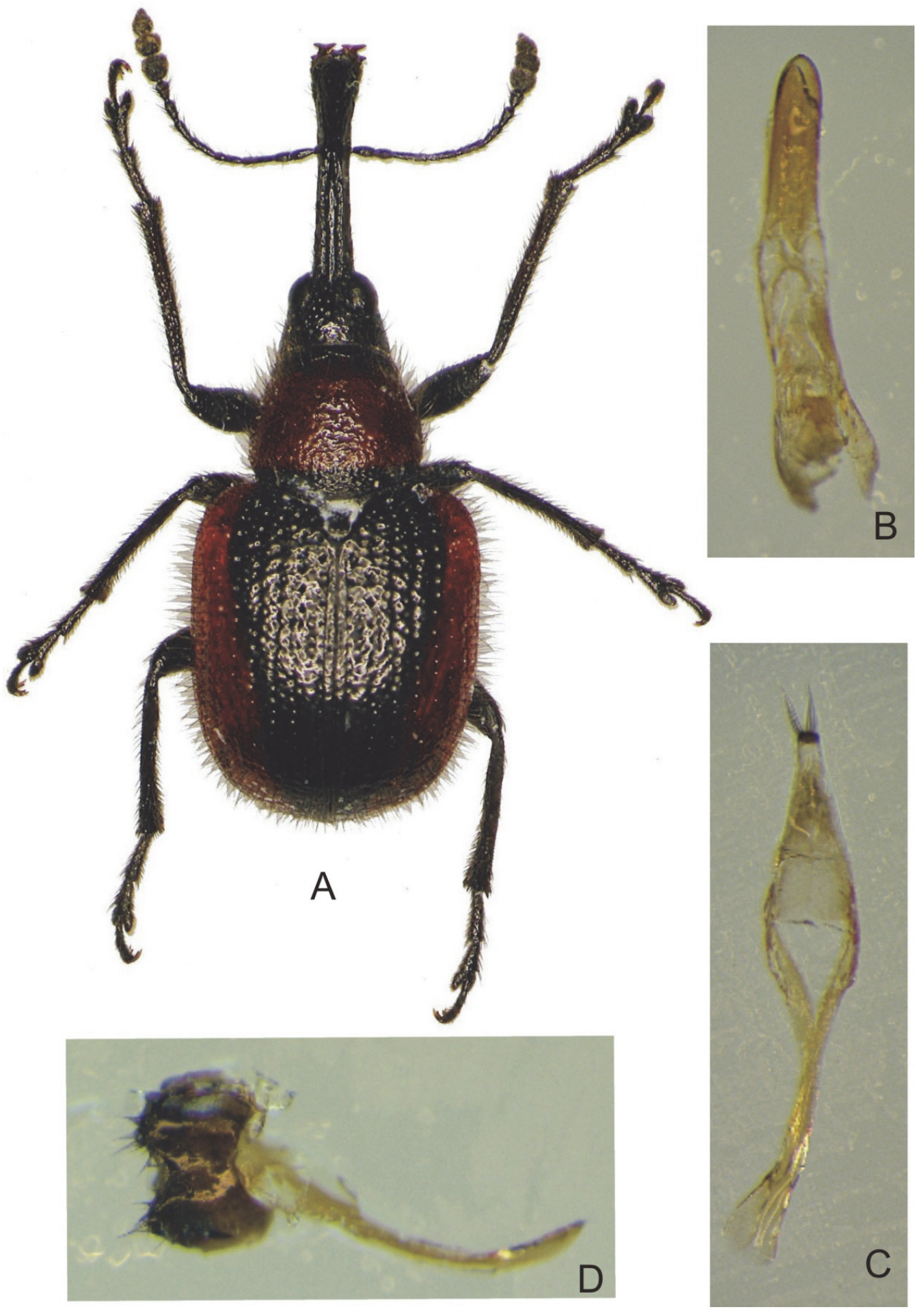

Figure 1. Mecorhis ungarica male individual and reproductive organs. A) adult, B) aedeagus, C) tegmen, D) tergit VIII and spiculum gastrale (Original). 

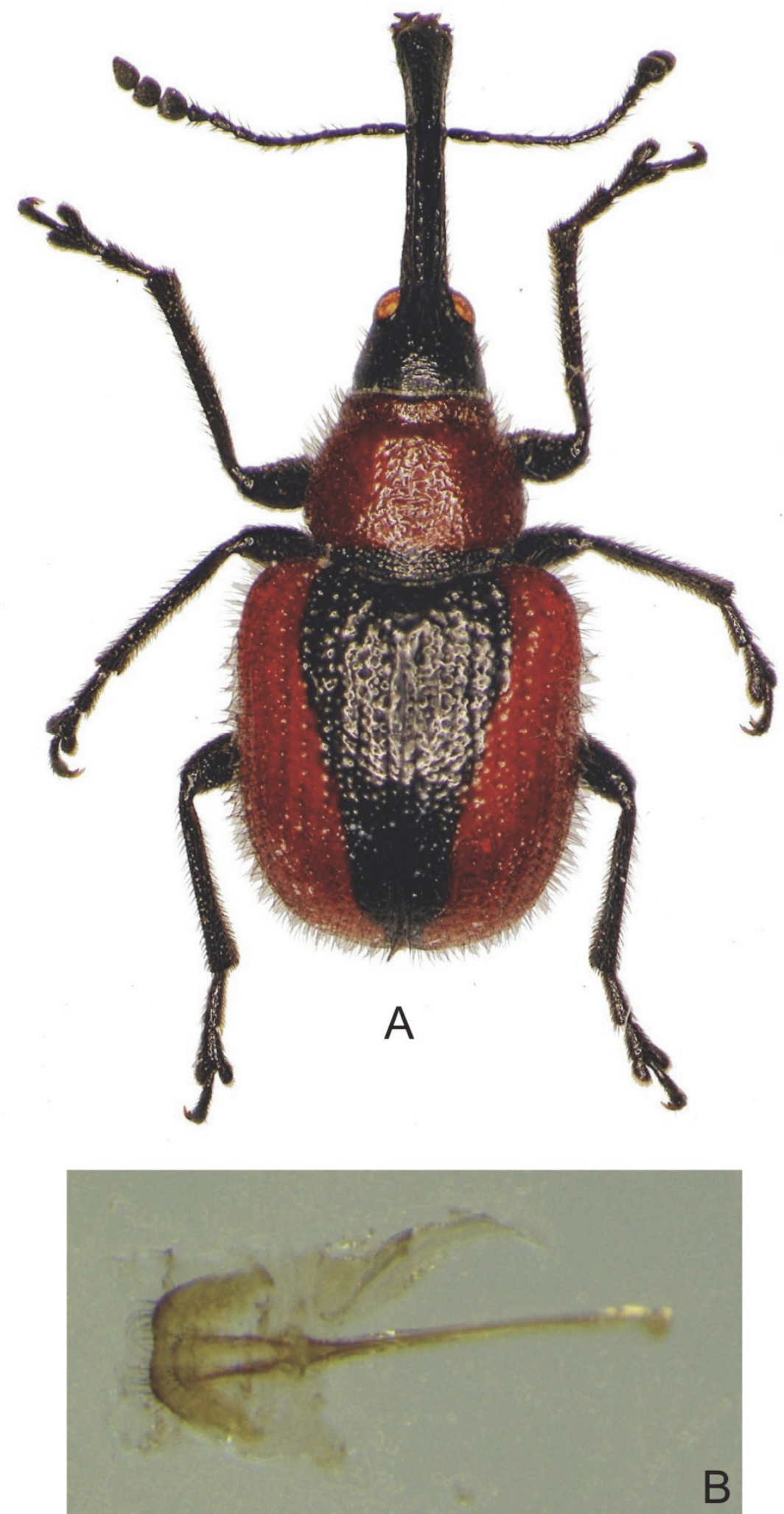

Figure 2. Mecorhis ungarica female individul and reproductive organs. A) adult, B) tergit VIII and spiculum ventrale (Original). 


\section{Egg (Figure 3. B. C.)}

The length of eggs varied from $1.10 \mathrm{~mm}$ to $1.50 \mathrm{~mm}$ (average: $1.37 \mathrm{~mm}, \mathrm{n}: 10$ ); the width from 0.70 $\mathrm{mm}$ to $1.00 \mathrm{~mm}$ (average: $0.88 \mathrm{~mm}, \mathrm{n}: 10$ ). Eggs are nearly oval. The colors are light yellow to straw yellow and their appearance is bright.

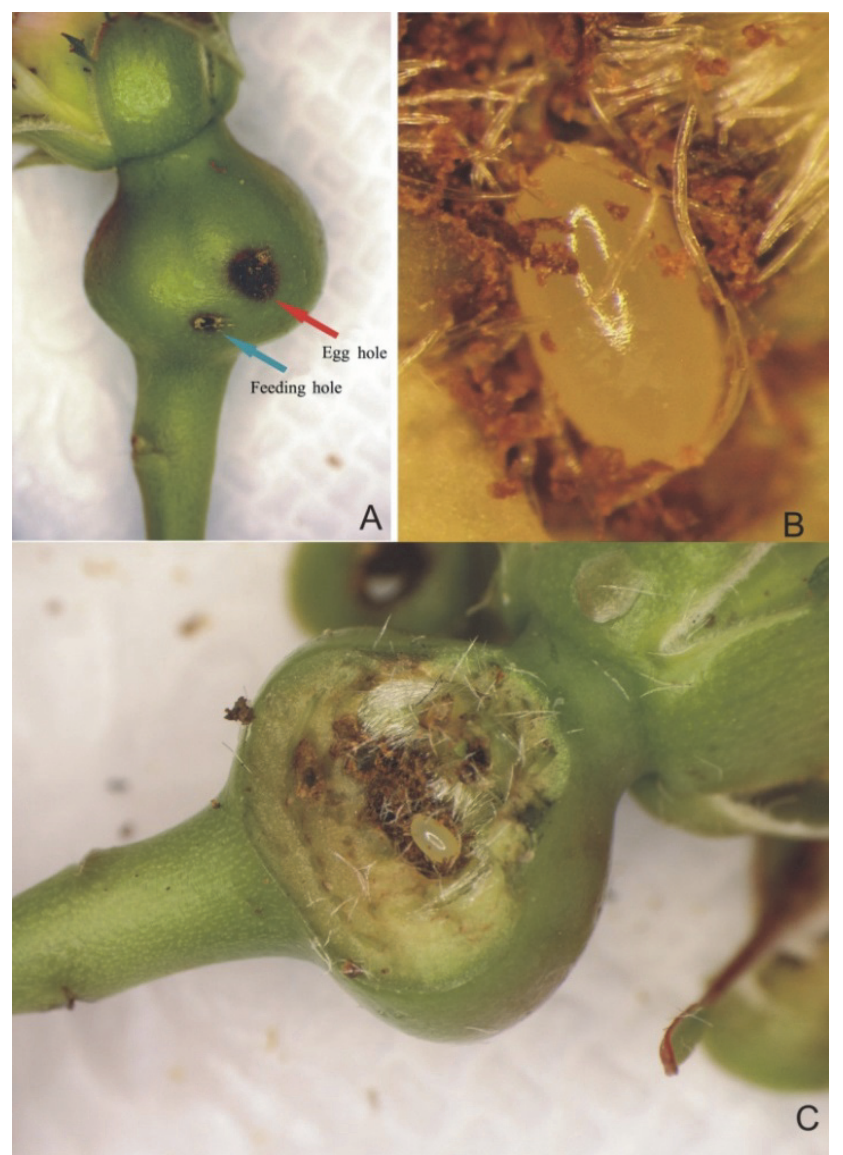

Figure 3. Feeding, eggs hole and eggs of Mecorhis ungarica. A) egg and feeding hole on rosehip, B-C) laid eggs into the fruit (Original).

\section{Larvae (Figure 4)}

For the determination of larval stages, 231 larvae collected during the field survey were investigated. The lengths and head capsule diameters of each of these were being measured under a microscope. However, the results of measurements obtained did not allow larval stages to seperate from each other (Figure 5). It was determined that the lengths and diameters of head capsule of mature larvae varied from $6.40 \mathrm{~mm}$ to $9.70 \mathrm{~mm}$ (average: $8.40 \mathrm{~mm}, \mathrm{n}: 10$ ) and from $0.72 \mathrm{~mm}$ to $0.96 \mathrm{~mm}$ (average: 0.84 $\mathrm{mm} \mathrm{n}: 10$ ) respectively. In mature larvae, setae, lateral eye and segments of body to be quite distinctive and colors of body to be darker yellow in comparison with first instar larvae.

\section{Pupae (Figure 6)}

Mature larvae of Mecorhis ungarica passed to pupal stage inside soil in early spring. The first pupa was detected in the third week of april. Pupal type was permissive; the rostrum reached to the abdomen, and legs were on both sides of rostrum and attached to the body. 


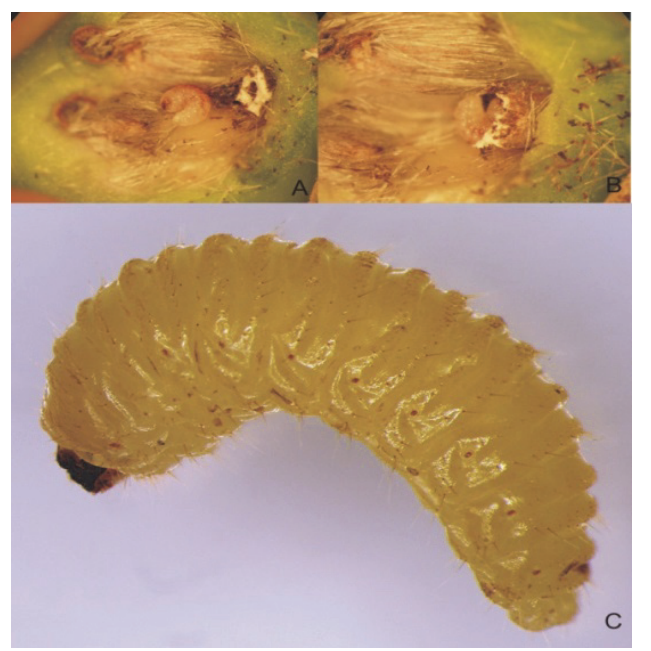

Figure 4. Different period of Mecorhis ungarica larvae A-B) first instar larvae C) mature larvae (Original)

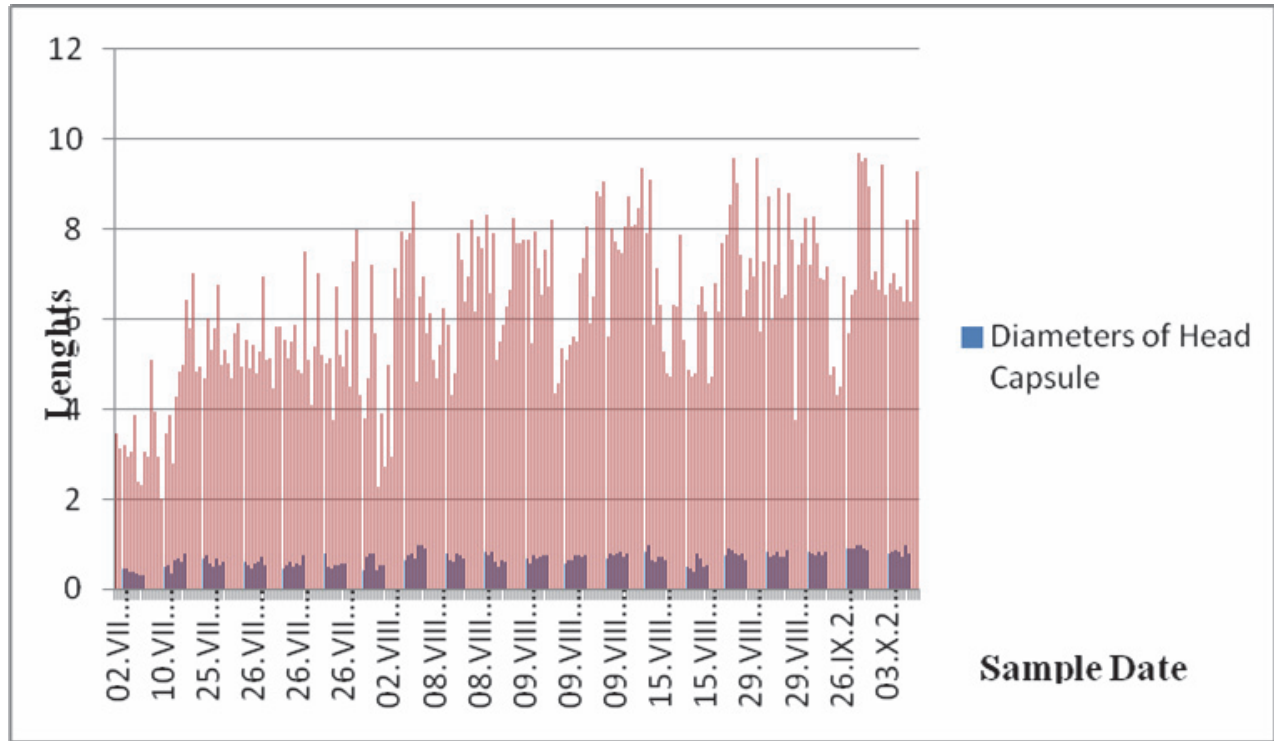

Figure 5. Larval stage of Mecorhis ungarica.

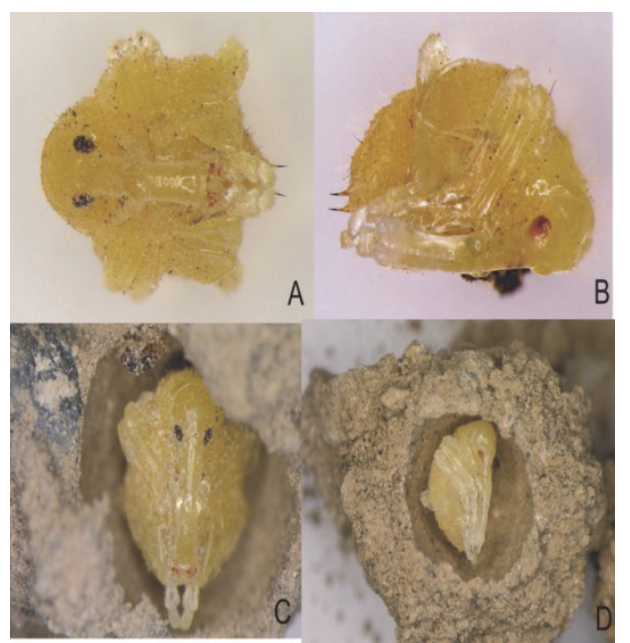

Figure 6. Mecorhis ungarica' pupa. A) ventral appearance B) lateral appearance C-D) pupa in the cocoon (Original). 


\section{Biology of Mecorhis ungarica}

Mecorhis ungarica spends the winter as mature larvae in the soil. According to this study, mature larvae (15.VIII.2007, Kemah; 03.IX.2007, Tercan) exited from fruit and fell down to the soil (Figure 7). They made a special cocoon at about 3-5 cm depth in the soil (23.VIII.2007), and spent the winter in this cocoon (Figure 7.B.C). They became pupae in the early spring (22.IV.2008). Studies showed that, adults appeared on rosehip plants starting from the second week of May (09.V.2007, 07.V.2008) at Erzincan conditions. Adult insects became active in the first rays of the sun. They immediately dropped to the ground in case of slightest danger, and remained immobile contracted in a ball on their back camouflaged in the soil. Their movements are agile. Good at flying. The adults reached sexual maturity after feeding aproximately one week, and pairs mated with each other on the host plants. Oviposition was observed in the middle of May (16.V.2007, 14.V.2008). At this time, rosehip was phenologically in the flower bud stage.

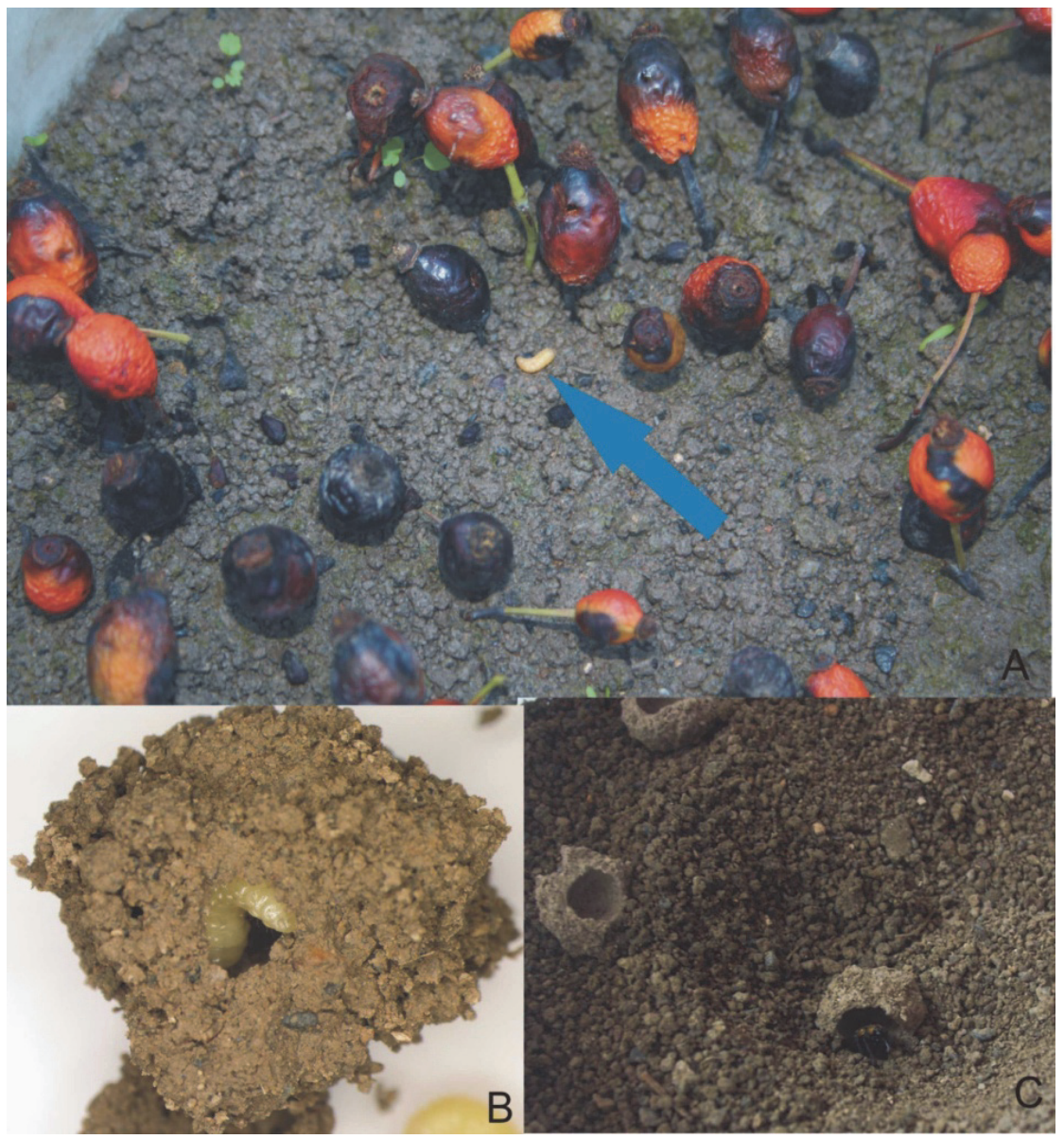

Figure 7. Hibernating of Mecorhis ungarica in soil. A) passing of larva in soil, B) mature larvae in the soil cocoon, C) new generation adult in soil cocoon (Original).

According to oviposition observations, drilling a hole on fruit takes 10-15 minutes to lay egg. Once completing drilling, the female turned backward to lay the egg, then turned foreward to push the egg into the fruit with the help of rostrum. After the egg was placed inside, the female closed over the egg by chewing the sides of the hole. Finally, the female sealed the ovipositon hole with a liquid secretion from the rostrum and this secretion turned black color and hardened with time. Ovipositon mark egg laid hole is 
easily distinguished from the feeding hole which is not closed by secretion (Figure 3.A). The oviposition period was approximately 40 days in the nature, and continued in the phenological blossom period of rosehip until the first week of July (04.VII.2007). In addition, adults destroyed stalks of buds and this is feeding damage. Some of the buds whose stalks were damaged fell off the plant and some remained hanging.

According to a study conducted in Ghoht and Kotaik districts in Armenia, adults were appeared from May to early July, females were laid their eggs into buds of rasehip plants, then cut their steams, the injured buds were withered and fell down (Rikhter and Ter-Minassian 1942).

Average daily egg production of a female was 1.2 (n: 10) at the last week of May (24.V.2007) under laboratory conditions; 1 egg was present in $50 \%$ of flower buds, 2 eggs $20 \%, 3$ eggs $10 \%$ and no eggs $20 \%$ (Table 2). Average daily egg production of a female was $1.6(n: 10)$ at the second week of July (12.VII.2007); 1 egg was present in $40 \%$ of fruits, 2 eggs $20 \%, 3$ eggs $10 \%, 5$ eggs $10 \%$ and no eggs $20 \%$ (Table 3).

Table 2. Daily fecundity of Mecorhis ungarica (24.V.2007).

\begin{tabular}{cccc}
\hline Jar Numbers & Number of flower bud & Number of holes & Number of eggs \\
\hline 1 & 2 & 13 & 2 \\
2 & 2 & 4 & 1 \\
3 & 2 & 9 & 1 \\
4 & 2 & 11 & 0 \\
5 & 2 & 18 & 2 \\
6 & 2 & 7 & 1 \\
7 & 2 & 21 & 3 \\
8 & 2 & 17 & 1 \\
9 & 2 & 14 & 0 \\
10 & 2 & 15 & \\
\hline
\end{tabular}

Table 3. Daily fecundity of Mecorhis ungarica (12.VII.2007).

\begin{tabular}{cccc}
\hline Jar Numbers & Number of flower bud & Number of holes & Number of eggs \\
\hline 1 & 2 & 15 & 1 \\
2 & 2 & 19 & 2 \\
3 & 2 & 14 & 1 \\
4 & 2 & 10 & 5 \\
5 & 2 & 18 & 2 \\
6 & 2 & 13 & 1 \\
7 & 2 & 17 & 0 \\
8 & 2 & 11 & 0 \\
9 & 2 & 8 & 3 \\
\hline
\end{tabular}

Avarage hatching period of $M$. ungarica adults' eggs was determined. In the analyzing of Table 4 average hatching duration of eggs of $M$. ungarica adults was found to be 10.1 ( $\mathrm{n:10}$ ) days under laboratory condition $\left(24-25^{\circ} \mathrm{C}\right)$. As for Tuatay (1963) according to her, the eggs hatch in 8-12 days. 
Investigation of the morphology, biology and infestation of Mecorhis ungarica (Herbst, 1783) (Coleoptera: Rhynchitidae) associated with rosehip plants (Rosa spp.)

Table 4. Determination of Mecorhis ungarica egg hatching duration.

\begin{tabular}{ccc}
\hline Jar Numbers & Number of buds & Egg hatching duration (day) \\
\hline 1 & 2 & 9 \\
2 & 2 & 8 \\
3 & 2 & 10 \\
4 & 2 & 10 \\
5 & 2 & 12 \\
6 & 2 & 10 \\
7 & 2 & 8 \\
8 & 2 & 11 \\
9 & 2 & 12 \\
10 & 2 & 11 \\
\end{tabular}

The first larva were detected in the first week of July (04.VII.2007) in nature. Newly hatched larvae were located within the seed (Figure 4.A-B), then moved out of the seed made galleries in fruit. Larvae completed growth from the begining of August (01.VIII.2007), then emerged from fruits and passed into soil (15.08.2007) (Figure 7). Larval development time was about 40-45 days (average: 42 days). In the end of January (29.I.2008), mature larvae were observed hibernating in the cocoons made from soil. When pots containing larvae were kept for $8-12$ hours under the room condition $\left(24-25^{\circ} \mathrm{C}, 10 ; 14\right.$ hours day and night), larvae broke hibernation and having actived in the soil.

The first pupa was observed in the end of third week of April (22.IV.2008), and first adult emergence was observed in the end of April (30.IV.2008) under field conditions. The last pupa was observed on 26.IV.2008, and adult emergence was completed on 06.V.2008. The average pupal development time 9.9 (n: 10) days. In the survey studies carried out in the nature, first adults were observed in the village of Dumanlı in the first week of May (07.V.2008). As a result, M. ungarica produce one generation per year under the Erzincan ecological conditions.

Table 5. The first pupae dates, pupae durations and the first mature emergence dates of Mecorhis ungarica.

\begin{tabular}{|c|c|c|c|}
\hline Pot numbers & The first pupae dates & Pupae durations & $\begin{array}{l}\text { The first mature } \\
\text { emergence dates }\end{array}$ \\
\hline 1 & 22. IV.2008 & 8 day & 30. IV.2008 \\
\hline 2 & 22. IV.2008 & 8 day & 30. IV.2008 \\
\hline 3 & 22. IV.2008 & 10 day & 02. V.2008 \\
\hline 4 & 22. IV.2008 & 12 day & 04. V.2008 \\
\hline 5 & 23. IV.2008 & 11 day & 04. V.2008 \\
\hline 6 & 24. IV.2008 & 12 day & 06. V.2008 \\
\hline 7 & 24. IV.2008 & 10 day & 04. V.2008 \\
\hline 8 & 25. IV.2008 & 9 day & 04. V.2008 \\
\hline 9 & 25. IV.2008 & 9 day & 04. V.2008 \\
\hline 10 & 26. IV.2008 & 10 day & 06. V.2008 \\
\hline
\end{tabular}

\section{Damage and Infestation Rate of Mecorhis ungarica}

Adults of Mecorhis ungarica lead to damage by making holes on buds, flowers and fruits of rosehip during oviposition. Also, adults in laying eggs, damage the stalks of the buds. When the buds and stalks were damaged, they shed on floor, some were exposed to dry by being remained hanging. The dense of 
pest populations and the bud or young periods of the plants lead to an increase in the rate of damage. Larvae become mature after feeding in the fruit, then opens the hole on the fruit, exit from there and fall down on the soil so it leads to damage on fruit of rosehip. Moreover the fruits including larvae and egg have a hole, as well as differences in the physical structure of the fruit (being in brownish color of infested fruit, as a result of feeding larvae in the fruit feeding scraps occuring, etc.) cause both qualitative and quantitative characteristics of rosehip fruit to decrease. Apart from these, sales appeal of rosehip fruit decreases. As for Rikhter and Ter-Minassian (1942) according to their, it was determined that in the injured buds, flovering and yeilding of fruit dicreased.

During the field surveys in 2007, total 3100 buds and fruits, 800 of which were buds and 2300 of which were fruits, were examined in the laboratory. According to this examination 144 buds were damaged by adults and infestation rate 18\%. Seventy six eggs were obtained from infested 144 buds $(52.8 \%)$ and the remaining $47.2 \%$ had adult feeding damage. Totally 728 fruits were found to be infested and infestation rate $31.7 \%$. Ten eggs and 241 larvae were acquired from these infested fruits. That is, while $1.4 \%$ and $33.1 \%$ of 728 damaged fruits were infested with eggs and larvae respectively. It is understood that $65.5 \%$ of them were feeding damage.

According to field surveys conducted in 2008 , total 2100 buds and fruits were harvested. Of these, 1500 were buds and 600 fruits. One hundred seventy three of buds were damaged by adults, infestation rate $11.5 \%$. Fifty four eggs were obtained from infested 173 buds. Percent $31.2 \%$ of the buds were infested with eggs and remaining $68.8 \%$ feeding damage by adult. Totally 164 fruits were found to be infested and infestation rate $27.3 \%$. Sixty seven eggs were acquired from these infested fruits. That is, while $40.9 \%$ of 164 damaged fruits were infested with eggs, it is understood that $59.1 \%$ of them were feeding damage. Feeding damage of adult insect was observed mostly in the fruit period and females prefer to lay eggs mostly in bud stage. As seen in the Figure 8 , while the maximum infestation rate was in Dumanlı village, it was followed by Hacıbayram and Dutlu villages.

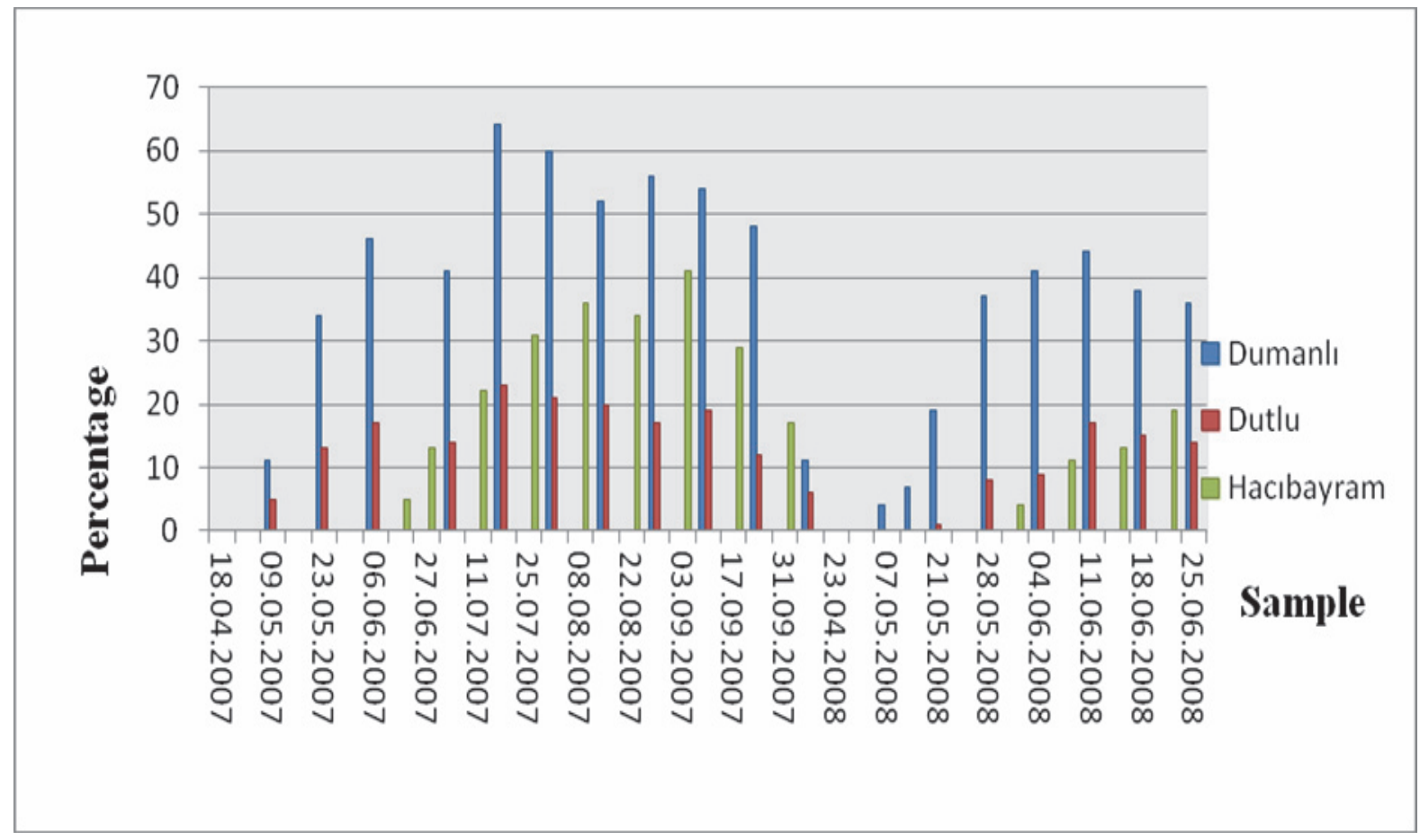

Figure 8. Infestation rate of Mecorhis ungarica in Erzincan province in 2007-2008. 
As seen in the Table 6, the first adult was found in Dumanlı village in the first week of May in 2008 and as a result of stroke it was determined that 28 adult fell in the Japanese umbrella. In Dutlu village, whereas first adult emergence occured in the third week of May, in Hacibayram village first adult emergence appeared in the first week of June (Figure 9). The difference of this time in the exit of the adult was thought to be caused the effect of elevation and phenology (Dumanlı: $1140 \mathrm{~m}$, Dutlu: $1105 \mathrm{~m}$, Hacıbayram: $1700 \mathrm{~m}$ ). However, although, the altitude of Dutlu village from survey areas is lower than that of Dumanlı village; in Dumanlı village emergence of adult was 2 weeks earlier. The reason of this contrast; around the rosehip locality in Dutlu is surrounded by tall poplar trees which shade the rosehips and delay spring warming. The first adults have emerged from the first week of the May and it is determined that the population density began to rise from that date. Among the survey areas the highest adult population density was in Dumanlı village.

Table 6. Adult population intensity and seasonal activity of Mecorhis ungarica in 2008.

\begin{tabular}{|c|c|c|c|c|c|}
\hline Dates & $\begin{array}{c}\text { Place } \\
\text { (Location) }\end{array}$ & $\begin{array}{c}\text { Total Number } \\
\text { of Bush }\end{array}$ & Number Stroke & $\begin{array}{c}\text { Number of } \\
\text { Adult counted }\end{array}$ & Fenology \\
\hline 23. IV.2008 & Dutlu & $71-150$ & $31-40$ & --- & Awakening of buds \\
\hline 23. IV.2008 & Dumanlı & $151-300$ & $41-80$ & --- & Awakening of buds \\
\hline 30. IV.2008 & Dutlu & $71-150$ & $31-40$ & --- & Awakening of buds \\
\hline 30. IV.2008 & Dumanlı & $151-300$ & $41-80$ & --- & Awakening of buds \\
\hline 07.V.2008 & Dutlu & $71-150$ & $31-40$ & --- & Bud \\
\hline 07.V.2008 & Dumanlı & $151-300$ & $41-80$ & 28 & Bud \\
\hline 14.V.2008 & Dutlu & $71-150$ & $31-40$ & --- & Bud \\
\hline 14.V.2008 & Dumanlı & $151-300$ & $41-80$ & 89 & Bud \\
\hline 21.V.2008 & Dutlu & $71-150$ & $31-40$ & 2 & Blooming \\
\hline 21.V.2008 & Dumanlı & $151-300$ & $41-80$ & 151 & Blooming \\
\hline 27.V.2008 & Hacıbayram & $71-150$ & $31-40$ & --- & Bud \\
\hline 28.V.2008 & Dutlu & $71-150$ & $31-40$ & 12 & Blooming \\
\hline 28.V.2008 & Dumanlı & $151-300$ & $41-80$ & 134 & Blooming \\
\hline 03.VI.2008 & Hacıbayram & $71-150$ & $31-40$ & 20 & Bud \\
\hline 04.VI.2008 & Dutlu & $71-150$ & $31-40$ & 16 & Blooming \\
\hline 04.VI.2008 & Dumanlı & $151-300$ & $41-80$ & 119 & Blooming \\
\hline 10.VI.2008 & Hacıbayram & $71-150$ & $31-40$ & 40 & Bud \\
\hline 11.VI.2008 & Dutlu & $71-150$ & $31-40$ & 26 & Fruit \\
\hline 11.VI.2008 & Dumanlı & $151-300$ & $41-80$ & 123 & Fruit \\
\hline 17.VI.2008 & Hacıbayram & $71-150$ & $31-40$ & 37 & Blooming \\
\hline 18.VI.2008 & Dutlu & $71-150$ & $31-40$ & 23 & Fruit \\
\hline 18.VI.2008 & Dumanlı & $151-300$ & $41-80$ & 96 & Fruit \\
\hline 24.VI.2008 & Hacıbayram & $71-150$ & $31-40$ & 32 & Blooming \\
\hline 25.VI.2008 & Dutlu & $71-150$ & $31-40$ & 15 & Fruit \\
\hline 25.VI.2008 & Dumanlı & $151-300$ & $41-80$ & 72 & Fruit \\
\hline
\end{tabular}




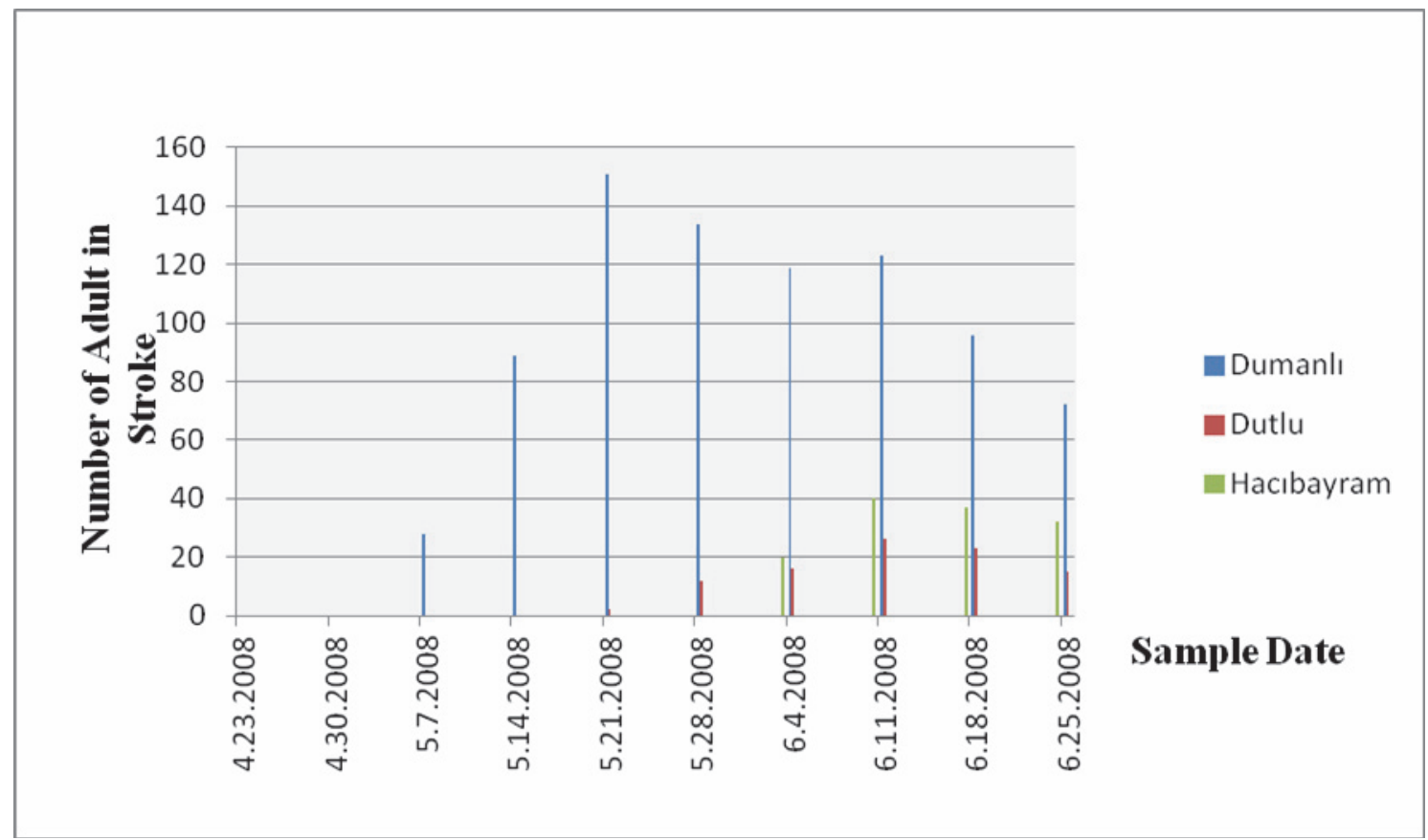

Figure 9. Population intensity of Mecorhis ungarica in Erzincan province in 2008.

In recent years, damage of this insect is started to be important in Erzincan province. To reduce the damage of this insect can be suggested physical precautions. Adults of $M$. ungaricus are quite passive move when they emerge in early spring. Considering this feature, in early spring when the adults emerge, their disposal in the form of hand-picked can be a physical struggle.

\section{Acknowledgement}

We would like to thank Professor Sezai Ercişli (Atatürk University, Faculty of Agriculture, Horticulture Department, Erzurum) who identified rosehip species and Dr. Sci. Andrei Legalov (Institute of Systematics and Ecology of Animals, Siberian Branch of Russian Academy of Science, Novosibirsk) for literature support and Dr. Lincoln Smith (USDA-ARS, Western Regional Research Center, Albany, California, USA) for valuable review of manuscript. This study was supported by General Directorate of Agricultural Research and Policies (Republic of Turkey Ministry of Food, Agriculture and Livestock, Ankara).

\section{References}

Alonso-Zarazaga, M.A. 2011. Rhynchitidae, pp. 109-129. In: Catalogue of Palaearctic Coleoptera. Vol. 7 (I. Löbl and A. Smetana, editors). Stenstrup, Apollo Books, 373 pp.

Bilginer, Ş., Ceyhan V., Karaduva L. \& Demirsoy H., 1996. Rosehip Potential of Samsun Province and Socioeconomic Characteristics of the Farmers Collecting Rosehip. Rosehip Symposium (5-6 September 1996, Gümüşhane, Turkey) Proceedings, $382 \mathrm{pp}$.

Çakırbay, İ.F., Alıcı, H. \& Bozbek, Ö., 2000. Studies on the Determination, Distribution and Population Intensity of Beneficial and Harmful Insects on Rosehip Plant (Rosa spp.) Naturally Growing in the Erzincan and Gümüşhane Provinces (Result Report) (Unpublished). Horticultural Research Station, Erzincan, Turkey, 17pp.

Davis, P.H., 1972. Flora of Turkey and The East Agean Island, Edinburg University Press, Edinburg, 657 pp.

Grigorov, S.P., 1974. Karantına na Restaniata. Zemizdat, Sofya, 346 pp. 
Kocamaz, C., \& Karakoç, A., 1994. Rosehip Selection for Variety Usage (Result Report). Directorate of Fruit Breeding Station, Tokat, Turkey.

Legalov, A.A., 2003. Diagnoses of New Taxa Described in "Legalov A.A. 2003. Taxonomy, classification and phylogeny of leaf-rolling weevils (Coleoptera: Rhynchitidae, Attelabidae) of the world fauna. Novosibirsk, 733 pp.

Legalov, A.A. 2005. Trophic relations of leaf-rolling weevils (Coleoptera, Rhynchitidae, Attelabidae). Zoologichesky Zhurnal, 84 (3): 352-361.

Legalov, A.A. \& Friedman A.L.L. 2007. Review of the Leaf-rolling Weevils of Israel (Coleoptera: Curculionoidea: Rhynchitidae and Attelabidae). Israel Journal of Entomology, 37: 181-203.

Legalov, A.A., 2007a. Leaf-rolling Weevils (Coleoptera: Rhynchitidae, Attelabidae) of the World Fauna. Novosibirsk: Agro-Siberia, $523 \mathrm{pp}$.

Legalov, A.A., 2007b. The Leaf-rolling Weevils (Coleoptera: Rhynchitidae, Attelabidae) from Orenburg Province. Altay zoological journal, 1: 35-36.

Özbek, H., Güçlü, S. \& Tozlu, G., 1996. Harmful Arthropoda Species on Rosehip Plants in Erzurum, Erzincan, Bayburt and Artvin Provinces. Rosehip Symposium (5-6 September 1996, Gümüşhane, Turkey) Proceedings, $382 \mathrm{pp}$.

Özbek, H. \& Çalmaşur, Ö., 2005. A Rewiev of Insects and Mites Associated with Roses in Turkey. Acta Horticulturae, 690: 167-174.

Reitter, E., 1916. Fauna Germanica. K. G. Lutz Verlag, Stuttgart, 5: 1-343.

Rikhter A.A. \& Ter-Minassian M.E., 1942. Novyi vreditel' shipovnika v Armyanskoi SSR - Rhynchites hungaricus Fuessly (Coleoptera, Curculionidae) (New pest of rosehip - Rhynchites hungaricus Fuessly (Coleoptera, Curculionidae) in Armenian SSR) // Bulletin of the Armenian Branch of the Academy of Sciences of the USSR, 7 (21): 81-85.

Tuatay, N., 1963. Studies on Mainly Pests, Brief Biology and Contol Methods of Oil Roses in Isparta and Burdur Region. Ankara Plant Protection Institute, Ankara, Turkey, 39: 78 pp.

User, T., 1967. A Studies on Vitamin C Status in Rosehip Growing in Central and North Anatolia Regions in Our Country and about People Traditions Related to this. Turkish Hygiene and Experience Journal of Biology, 21 (2): 52-60. 